\title{
Bioetyka żydowska wobec początków i końca życia
}

Slowa kluczowe: preimplantacyjna diagnostyka genetyczna, embrionalne komórki macierzyste, bioetyka, judaizm, aborcja, eutanazja

Według Van Rensselaera Pottera (1911-2001) - amerykańskiego onkologa, który wprowadził pojęcie bioetyki do współczesnego dyskursu naukowego - bioetyka to wiedza o tym, jak używać wiedzy. W swoim pierwotnym projekcie wyłożonym w książce Bioethics. Bridge to the Future, stwierdził, że zastosowania biomedycyny powinny być poprzedzone rozważaniami aksjologicznymi ${ }^{1}$. Bezrefleksyjne i bez poszanowania wartości moralnych używanie narzędzi takich, jak rekombinacje DNA, terapie genowe, transplantacja organów, i innych procedur, wyrządzić może więcej szkód ludziom, społeczeństwu i równowadze ekologicznej na świecie niż korzyści. Wartości, jakie powinny przyświecać zastosowaniom współczesnej biomedycyny, są przedmiotem burzliwych debat ${ }^{2}$. Nie inaczej jest $w$ judaistycznym i izraelskim dyskursie bioetycznym.

W artykule przedstawię charakterystykę bioetyki w Izraelu, opierającej się w dużej mierze na żydowskim prawie i tradycji religijnej. Judaistyczna bioetyka jest złożona, gdyż różnice między ortodoksyjnymi, konserwatywnymi i reformowanymi odłamami judaizmu przekładają

${ }^{1}$ V.R. Potter, Bioethics. Bridge to the Future, New Jersey 1971, s. 2-20.

2 D. Müller, The Role and Influence of Religions in Bioethics, [w:] R.M. Green, A. Donovan, S.A. Jauss (red.), Global Bioethics. Issues of Conscience for the TwentyFirst Century, Oxford 2008. 
się na dyskusje bioetyczne, jednak w wielu kwestiach, jak zapłodnienie in vitro, badania na komórkach macierzystych, w tym embrionalnych komórkach macierzystych, czy eutanazja, wypracowano szeroki konsensus. Najogólniej rzecz ujmując, żydowska bioetyka - podobnie jak bioetyka islamska i konfucjańska - jest bardziej otwarta na możliwość sztucznego zapłodnienia metodą in vitro niż w przypadku propozycji katolickich, a także bardziej otwarta na $\mathrm{PDG}^{3}$, klonowanie, badania na embrionach i embrionalnych komórkach macierzystych niż wiele koncepcji i europejskich rozwiązań prawnych. Prowadzi to do niekonsekwentnych z europejskiego punktu widzenia rozwiązań legislacyjnych w Izraelu, z jednej strony dopuszcza się w praktyce aborcję na żądanie, preimplantacyjną diagnostykę genetyczną czy zapłodnienie in vitro, obowiązuje swoboda badań na embrionalnych komórkach macierzystych, co lokuje Izrael $\mathrm{z}$ zachodniego punktu widzenia na pozycjach skrajnie liberalnych, z drugiej - eutanazja i wspomagane samobójstwo są zabronione, co zbliża Izrael do stanowisk konserwatywnych i katolickich. Ta pozorna jedynie niekonsekwencja wynika ze specyfiki judaizmu i jego kazuistycznej etyki.

W mojej pracy przeanalizuję wybrane problemy współczesnej bioetyki w Izraelu, takie jak aborcja, klonowanie, status życia embrionalnego oraz jego konsekwencje dla eksperymentów na ludzkich embrionalnych komórkach macierzystych, oraz problematykę orzekania śmierci i pobierania organów od zmarłych. Od bioetyki judaistycznej, odnoszącej się bezpośrednio do źródeł i autorytetów religijnych, która stanowi materiał na osobną pracę, odróżniam dyskurs bioetyczny w Izraelu, który zawiera debaty i akcje społeczne, praktyki, organizacje popularne w tym kraju. Celem badawczym pracy jest odpowiedź na pytanie, na ile judaistyczne podejście do wybranych kwestii bioetycznych obecne jest w świadomości Izraelczyków, czy są to kwestie żywe w zsekularyzowanym, nowoczesnym społeczeństwie Izraela i czy w znaczący sposób wpływa ono na prawo w tym państwie?

\section{Status embrionów i płodów w bioetyce judaistycznej}

Żydowskie prawo religijne i etyka opierają się na kilku podstawowych źródłach: Torze, Misznie, a także Talmudzie, zawierającym komentarze do Miszny oraz tradycji rabinicznej. Prawa i reguły w nich zawarte mają charakter kazuistyczny, co bezpośrednio przekłada się

${ }^{3}$ Preimplantacyjna diagnostyka genetyczna (PDG) poprzedzać może implantację zarodka do macicy i ma na celu wykrywanie chorób genetycznych u zarodków. Do macicy wszczepiane są zarodki pozbawione określonej chorobotwórczej mutacji. 
także na współcześnie podejmowane zagadnienia bioetyczne. Przykładem może być status życia prenatalnego i jego konsekwencje dla takich kwestii, jak aborcja, zapłodnienie in vitro, badania na ludzkich embrionach, klonowanie itp. W rozważaniach nad tym zagadnieniem żydowscy hermeneuci odwołują się do biblijnego opisu sytuacji z Księgi Wyjścia, w której mężczyzna bije kobietę w ciąży i ona w następstwie tego brutalnego ataku traci dziecko ${ }^{4}$. Jeśli w konsekwencji tego zdarzenia kobieta umrze, mężczyzna karany jest śmiercią, na zasadzie oko za oko, ząb za ząb. Jeśli kobieta przeżyje, ale poroni, złoczyńca zobowiązany jest do wypłaty pewnej finansowej rekompensaty za stratę nienarodzonego dziecka. Wynika stąd wniosek, że uśmiercenie nienarodzonego dziecka nie jest traktowane jak morderstwo dorosłego ${ }^{5}$. $\mathrm{Z}$ drugiej jednak strony nie jest też bezkarne, a więc życie prenatalne ma pewną wartość, ale nie bezwzględną i nierówną życiu kobiety albo osoby dorosłej.

W Talmudzie natomiast stwierdza się, że aborcja dokonana, aby uratować życie matki, jest nie tylko dopuszczalna, ale także w takiej sytuacji wskazana, ponieważ życie matki uważane jest za ważniejsze od życia płodu. Innymi słowy życie nienarodzonego dziecka może zostać poświęcone dla dobra matki. W przypadkach aborcji z innych przyczyn, np. kobieta nie chce mieć kolejnego dziecka, usunięcie płodu jest uważane za poważne wykrocznie, ale zabieg nie jest traktowany jak morderstwo ${ }^{6}$. Jednakowoż zabicie noworodka lub usunięcie płodu ze względu na jego ewentualne wady fizyczne nie znajduje poparcia i jest zdecydowanie krytykowane przez wielu współczesnych rabinów, odrzucających aborcję eugeniczną.

Podsumowując, płód lub embrion nie przedstawiają takiej samej wartości, jak życie narodzonego dziecka (a ściślej noworodka od momentu, kiedy w kanale rodnym pojawi się głowa lub inna główna część ciała), jednak nie oznacza to, że nie powinny być one w pewien sposób chronione. Świadczy o tym reguła, że aby ratować nienarodzone jeszcze dziecko, można złamać prawo szabatu, co czyni się w wypadkach, kiedy stawką jest życie ludzkie ${ }^{7}$. Płód nie posiada tego samego statusu moralnego i prawnego, jak dziecko czy osoba dorosła, jego wartość nie jest bezwarunkowa, ale też nie powinien być bezmyślnie

\footnotetext{
${ }^{4}$ Księga Wyjścia, 21:22-23.

${ }^{5}$ I. Jakobovits, Jewish Views on Abortion, [w:] F. Rosner, D.J. Bleich (red.), Jewish Bioethics, New York 1983, s. 120-121.

${ }^{6}$ D.J. Bleich, Abortion in Halakhic Literature, [w:] F. Rosner, D.J. Bleich (red.), Jewish Bioethics, New York 1983, s. 136.

${ }^{7}$ I. Jakobovits, dz. cyt., s. 123.
} 
niszczony czy uszkadzany ${ }^{8}$ W tradycji rabinicznej pojawia się również rozróżnienie na aborcję mechaniczną, polegającą na usunięciu poszczególnych części ciała płodu, oraz na aborcję chemiczną, wywołaną pośrednio, czyli przez użycie np. ziół. Obie formy były uznawane przez Majmonidesa za uzasadnione wyłącznie w wypadku zagrożenia życia matki ${ }^{9}$. Jednak ten drugi sposób jest uważany za mniejsze zło w przypadku konieczności przeprowadzenia zabiegu przerwania ciąży dla ratowania matki.

W literaturze rabinicznej znajduje się również stwierdzenie, że embrion do 40. dnia od poczęcia nie jest nienarodzonym dzieckiem, co raczej „zaledwie wodą”, dlatego poronienie (lub aborcja) do 40 . dnia rozwoju nie powoduje u kobiety rytualnej nieczystości związanej z narodzinami dziecka ani też nieczystości związanej z kontaktem ze zwłokami ${ }^{10}$. Ten niejednoznaczny stosunek do życia płodowego do 40. dnia embrion nie jest uważany za życie ludzkie, potem jest życiem ludzkim, ale aborcja nie jest równoznaczna z morderstwem - prowadzi do następujących rozstrzygnięć w kwestii współczesnej biomedycyny: aborcja w celu ratowania życia lub zdrowia matki jest dozwolona, aborcja w innych przypadkach nie powinna być przeprowadzana, jednak nie równa się ona zabiciu dziecka. Fred Rosner i Edward Reichman stwierdzają, że większość autorytetów rabinicznych zgadza się, że preembriony przed implantacją nie mają tego samego statusu, co embriony i płody implantowane w ciele matki, nie odnosi się więc do nich argumentacja dotycząca zakazu aborcji. Ich status zbliżony jest raczej do męskiego nasienia ${ }^{11}$. Ze względu na niejednoznaczny status zarodków do 40. dnia rozwoju pobieranie komórek macierzystych od embrionów, a także eksperymenty na zarodkach mające prowadzić do wynalezienia nowego leku czy terapii są dozwolone ${ }^{12}$.

Również sztuczne zapłodnienie metodą in vitro, wiążące się z dokonywaniem procedur na embrionach, jest dozwolone pod warunkiem, że dawcą spermy jest małżonek, a dawczynią komórki jajowej żona, tak aby uniknąć zamieszania relacji rodzinnych, uniknąć możliwości kazirodztwa czy cudzołóstwa. Według wielu autorytetów religijnych

${ }^{8}$ D.J. Bleich, dz. cyt., s. 135, 137.

9 Tamże, S. 139.

${ }_{10}$ Tamże, s. 143-144.

${ }^{11}$ F. Rosner, E. Reichman, Embryonic Stem Cell Research in Jewish Law, "The Journal of Halacha and Contemporary Society” 2002, nr XLIII, s. 57-58.

${ }_{12}$ D. Eisenberg, Stem Cell Research in Jewish Law, http://www.jlaw.com/Articles/ stemcellres.html [dostęp: 28.08.2015]. 
implantacja zarodka nie powinna jednak przypadać na czas rytualnej nieczystości kobiety, tj. w czasie okresu, kiedy to stosunki seksualne są zakazane ${ }^{13}$. Sztuczne zapłodnienie pozwala wypełnić podstawowe zadanie człowieka, jakim jest prokreacja, zgodnie z biblijnym zaleceniem o rozmnażaniu się i czynieniu ziemi sobie poddaną $\mathrm{w}$ sytuacji, kiedy naturalne metody zawiodą.

Pozytywne podejście do wspomaganej reprodukcji reprezentowane przez judaistyczną bioetykę przekłada się bezpośrednio na postawy izraelskiego społeczeństwa. Techniki zapłodnienia in vitro są nie tylko dozwolone prawnie, ale także sięgają po nie pacjenci zarówno niereligijni, jak i należący do środowisk ortodoksyjnych żydów ${ }^{14}$. Ortodoksyjni żydzi akceptują wspomaganą reprodukcję, widząc w niej nadzieję na potomstwo. Co więcej, połącznie zapłodnienia in vitro z preimplantacyjną diagnostyką genetyczną jest preferowane przez konserwatywnych i reformowanych żydów w przypadkach dziedzicznych chorób genetycznych, takich jak na przykład choroba Tay-Sachsa, pozwala bowiem uniknąc aborcji na dalszych etapach rozwoju płodu, zamiast tego do macicy implantowane są jedynie zarodki pozbawione szkodliwej mutacji, przynoszącej dziecku śmierć w ciągu pierwszych lat życia ${ }^{15}$.

Potwierdza się zatem, że o ile procedury wykonywane na embrionach nie budzą sprzeciwu moralnego nawet wśród środowisk ortodoksyjnych, to aborcja znacznie bardziej rozwiniętego płodu spotyka się z dużymi zastrzeżeniami osób religijnych, chociaż dopuszcza się ją w przypadku zagrożenia życia matki, a także jej dobrostanu psychicznego. Natomiast osoby niereligijne zdecydowanie popierają prawo kobiet do aborcji, a społeczna akceptacja dla tego prawa rosła od lat 70. XX w., kiedy zalegalizowano aborcję w przypadku, gdy ciąża zagraża życiu matki, jest wynikiem gwałtu, stwierdzono nieprawidłowości rozwojowe płodu lub gdy dziewczyna jest niepełnoletnia albo kontynuowanie ciąży może być niebezpieczne dla zdrowia psychicznego kobiety. W 2014 r. wprowadzono prawo dopuszczające aborcje na żądanie, która pod określonymi warunkami jest finansowana przez

${ }^{13}$ F. Rosner, Artificial Insemination in Jewish Law, [w:] F. Rosner, D.J. Bleich (red.), Jewish Bioethics, New York 1983, s. 115.

${ }^{14}$ Informator: mężczyzna, 45 lat, członek społeczność ortodoksyjnej „Góra Kalwaria”, Bnei Brak, ojciec 3 dzieci poczętych dzięki sztucznemu zapłodnieniu techniką in vitro.

15 A.E. Raz, Y. Vizner, Carrier matching and collective socialization in community genetics: Dor Yeshorim and the reinforcement of stigma, "Social Science and Medicine" 2008, nr 67, s. 1361-1369. 
państwową służbę zdrowia, lokując tym samym Izrael wśród krajów o najbardziej liberalnym prawie pod tym względem ${ }^{16}$.

Brak jednoznacznego, bezwarunkowego, uświęconego statusu życia embrionalnego na najwcześniejszych etapach rozwoju, nawet wśród najbardziej konserwatywnych odłamów judaizmu, przekłada się na pozytywny stosunek do badań na ludzkich embrionach, jak i embrionalnych komórkach macierzystych. Zasadniczo judaizm nie nadaje embrionom przed implantacją statusu moralnego, w związku $\mathrm{z}$ tym tworzenie zarodków ludzkich metodą in vitro czy przez klonowanie nie jest zabronione. Co więcej, jeśli takie procedury służyć mogą walce $\mathrm{z}$ chorobą, leczeniu bezpłodności lub podobnym celom medycznym, to ich przeprowadzanie jest etycznie nie tylko usprawiedliwione, ale nawet konieczne i wymagane. Powyższe wnioskowanie przekłada się na sytuację prawną w Izraelu, badania na ludzkich embrionach i embrionalnych komórkach macierzystych są legalne i intensywnie prowadzone w wielu izraelskich instytucjach naukowych ${ }^{17}$. Za swój główny cel uznają leczenie chorób degeneracyjnych, a same embriony są pozyskiwane z klinik leczenia niepłodności, gdy nadliczbowe, niewykorzystywane do zapłodnienia zarodki są oddawane przez rodziców na cele naukowe.

\section{Klonowanie ludzi a bioetyka judaistyczna}

Zasadniczą troską żydowskiego podejścia do klonowania nie jest status moralny embriona, ale potencjalne zagrożenie osób sklonowanych dyskryminacją, stygmatyzacją i ostracyzmem, brakiem jednoznacznie określonego pochodzenia i niejasnością relacji rodzinnych. Źródeł tejże progresywnej postawy szuka się w Torze, gdzie znajdują się świadectwa mówiące o tym, że ludzie już w czasach biblijnych stosowali różne metody uprawy roślin czy hodowli zwierząt, aby poprawić ich wydajność i jakość. Były one w istocie rodzajem manipulacji (dokonywanej przez dobieranie do rozrodu odpowiednich osobników o pożądanych cechach fenotypowych $)^{18}$.

${ }^{16}$ D. Kamin, Israel's abortion law now among world's most liberal, "The Times of Israel”, http://www.timesofisrael.com/israels-abortion-law-now-among-worlds-mostliberal/ [dostęp: 6.11.2017].

17 Zob. http://www.hadassah-med.com/medical-care/clinics/gene-therapy/humanembryonic-stem-cell-research-center oraz http://nocamels.com/2014/02/five-israelicompanies-using-stem-cells-to-change-the-face-of-medicine/ [dostęp: 6.11.2017].

${ }_{18}$ M.Y. Barilan, The debate on human cloning: some contributions from the Jewish tradition, [w:] H. Roetz (red.), Cross-Cultural Issues in Bioethics: The Example of $\mathrm{Hu}$ man Cloning, New York 2006, s. 312. 
Odnosząc się do zagadnienia klonowania, izraelski lekarz Y. Michael Barilan, zajmujący się kwestiami bioetycznymi z żydowskiej perspektywy, utrzymuje, że genetyczna identyczność nie powinna mieć etycznej kwalifikacji. Krytycznie odnosi się do popularnej na Zachodzie i w kręgach chrześcijańskich koncepcji, że niepowtarzalność poszczególnych jednostek sama w sobie jest wartością, którą należy chronić, choćby przez zakaz klonowania reprodukcyjnego. Identyczne genetycznie są bliźnięta jednojajowe i nikt wcześniej nie podnosił ich życia do rangi problemu etycznego, argumentuje Barilan. Ponadto klonowanie nie implikuje zmiany natury, ale jej naśladowanie. Nie jest więc przekroczeniem jej praw. Inne niebezpieczeństwa wyłaniają się natomiast wraz z potencjalną, choć czysto hipotetyczną masowością klonowania ludzi. Masowość produkcji klonów przebiegać może w dwojaki sposób, po pierwsze jako wielokrotne klonowanie tej samej osoby, po drugie jako klonowanie stosowane przez wielu ludzi przy użyciu różnych (za każdym razem innych) dawców jądra komórkowego. Ta pierwsza sytuacja lokuje się raczej w sferze science-fiction. Natomiast klonowanie traktowane jako technika wspomaganej reprodukcji nie spowoduje prawdopodobnie przełomu demograficznego, ponieważ niepłodność nie jest powszechnym problemem medycznym. Barilan nie widzi więc $\mathrm{w}$ klonowaniu zagrożenia demograficznego ani społecznego.

Barilan podkreśla, że godność jest podstawową wartością w świecie judeochrześcijańskim. Jednak interpretacja tego pojęcia jest zupełnie inna $\mathrm{w}$ judaizmie niż $\mathrm{w}$ chrześcijaństwie. $\mathrm{W}$ pojęciu chrześcijańskim godność przynależy się każdej osobie ludzkiej, ma charakter metafizyczny, normatywny i niezbywalny ${ }^{19}$. Dlatego zwłaszcza w nauczaniu Kościoła rzymskokatolickiego można mówić nawet o godności zarodków (pre-embryons ${ }^{20}$ ), ponieważ przynależą one do gatunku homo sapiens sapiens, a więc są częścią rodziny ludzkiej. Godność $\mathrm{w}$ tym rozumieniu jest jakością niezbywalną i nierelatywną, przysługuje człowiekowi od poczęcia do śmierci. W tym miejscu zaznacza się odmienność tradycji żydowskiej, w której pojęcie godności pojawia się głównie w kontekście postępowania ze zwłokami, martwym ludzkim ciałem ${ }^{21}$, któremu winny jest szczególny szacunek.

Powołując się na halachę, judaistyczną tradycję religijną, Barilan konstatuje, że miłość bliźniego jest absolutna i ważniejsza od obowiąz-

${ }^{19}$ W. Gubała, Jan Pawet II o etyce lekarskiej, [w:] P. Morciniec (red.), Ad libertatem in veritate, Opole 1996, s. 263-264.

${ }^{20}$ Pojęcie pre-embryon odnosi się do rozwoju zarodkowego do 14. dnia rozwoju, przed implantacją $\mathrm{w}$ ścianie macicy.

${ }^{21}$ M.Y. Barilan, dz. cyt., s. 314. 
ku szacunku dla godności ludzkiej. Godność jest więc tutaj wartością drugorzędną. Ponadto Barilan stwierdza jednoznacznie, że miłość bliźniego wedle Talmudu rozpoczyna się po urodzinach dziecka ${ }^{22}$. Mimo iż Talmud wielokrotnie odnosi się do płodów jako do istot ludzkich, nigdy jednak nie określa się ich etycznego czy metafizycznego statusu jako równego urodzonemu już człowiekowi. Powyższą tradycję traktowania życia prenatalnego sankcjonuje współczesne rabiniczne stanowisko wobec zarodków, embrionów i płodów - nie podnosi się kwestii ich godności, bo nawet jeśli są w jakimś stopniu nią obdarzone, to zdrowie, dobrostan i interes osób żyjących (i narodzonych) jest priorytetowy.

W judaistycznej wizji życia, gdzie centralne miejsce zajmuje posiadanie potomstwa i małżeństwo, wspomaganie prokreacji, na przykład przez technikę zapłodnienia in vitro czy przez hipotetyczną możliwość klonowania, zyskuje, jak stwierdza rabin Moshe Tendler, nie tylko przyzwolenie, ale także moralne oraz religijne uzasadnienie. W jednym ze swoich przemówień stwierdza jednoznacznie, że nie wahałby się w pozytywnej ocenie klonowania w przypadku bezpłodnego mężczyzny, jedynego w rodzinie ocalałego z Holokaustu, gdyby klonowanie było jedyną metodą na spłodzenie potomstwa ${ }^{23}$. Natomiast dylematy związane z utylizacją, wykorzystywaniem zarodków czy embrionów do celów badawczych nie są tak palące, skoro nie uznaje się ich osobowego statusu.

Dominująca w Izraelu interpretacja przyjmująca nieokreślony status zarodka czy embriona ludzkiego albo odrzucający ich status osobowy jest niezgodna $\mathrm{z}$ odrzucaniem aborcji w ortodoksyjnym i konserwatywnym wydaniu judaizmu. Wskazuje to na obowiązek ochrony życia poczętego w późniejszych fazach rozwoju, nawet jeśli nie jest on wprost albo w jednoznacznie normatywny sposób wyrażany. Jednak nie dotyczy to embrionów przed implantacją do 40. dnia rozwoju.

Natomiast pozytywna postawa wobec sztucznego zapłodnienia techniką in vitro, obecna nawet wśród środowisk konserwatywnych i ortodoksyjnych, abstrahując od losu nadliczbowych embrionów niepoddawanych implantacji, zasadza się na postrzeganiu małżeństwa i posiadania dzieci w judaizmie jako podstawowego obowiązku każdego człowieka. Używanie sztucznych technik wspomagania reprodukcji zyskuje w judaizmie podatny grunt ze względu na jego konsekwentny antynaturalizm. Za podstawę tejże antynaturalistycznej postawy uzna-

22 Tamże.

${ }^{23}$ Zob. M. Tendler, Cloning in Jewish Law, YU Medical Ethics: Creating in God's Image?, Yeshiva University, 23.01.2003, https://www.yutorah.org/lectures/lecture. cfm/717528/rabbi-moshe-d-tendler/cloning-in-jewish-law/ 28-31min [dostęp: 7.07.2018]. 
je się biblijną sentencję: „,napełnijcie Ziemię i uczyńcie ją sobie poddaną". W judaizmie nie istnieje zagadnienie łamania praw natury, występowania przeciw naturze, przeszkadzania naturze, co jest typowe dla myślenia chrześcijańskiego ukształtowanego przez arystotelesowską i tomistyczną koncepcję prawa natury ${ }^{24}$. W judaizmie nie ma obiekcji wobec zmiany, ulepszania czy znacznego nawet przekształcania natury. Zmienianie przyrody na lepsze jest postrzegane pozytywnie, ponadto to, jak rozumiane jest „to lepsze”, mówi Barilan, zależy od ludzkiej oceny zjawiska ${ }^{25}$. W Torze znajdują się pewne zakazy dotyczące postępowania ze światem przyrody, jak zakaz krzyżowania międzygatunkowego niektórych zwierząt i roślin ${ }^{26}$. Inne formy biotechnologii są jednak dopuszczane, zakaz jest interpretowany bardzo dosłownie i wąsko.

Ze względu na dyskursywny charakter judaizmu pojawiają się też opinie rabiniczne, odrzucające możliwość tworzenia nowych gatunków, czyli rozszerzające wskazane w Torze wypadki na ogólną zasadę wobec świata przyrody. Nigdy nie jest to jednak skierowane przeciw biotechnologii jako takiej. Na przykład izraelski rabin i bioetyk Avraham Steinberg odrzuca tworzenie hybryd międzygatunkowych, ponieważ jest to czynność tworzenia gatunków zarezerwowana wyłącznie dla Boga. Pozytywnie za to odnosi się do klonowania ludzi i zwierząt, ponieważ oznacza ono kopiowanie tego, co i tak już istnieje i zostało stworzone przez Boga ${ }^{27}$.

Barilan zauważa pewną słabość niejednoznacznego, dyskursywnego i kazuistycznego stanowiska judaizmu w kwestiach bioetycznych - wobec braku systematycznej, całościowej analizy pojawia się tendencja do suchego formalizmu i braku wyczucia dla złożonych spraw ludzkiego życia. Silny nacisk na kazuistyczny charakter etyki, brak rozwiniętej refleksji metafizycznej w judaizmie powoduje, stwierdza Barilan, że kwestia destrukcji zarodków ludzkich lokuje się daleko poza przykazaniem nie zabijaj. Przywołuje futurystyczną wizję postępu biotechnologii, która doprowadziłaby w przyszłości do skonstruowania sztucznej macicy i pozwoliłaby na pełny rozwój zarodków powstałych metodą in vitro. Jaki byłby ich status? Czy mogłyby być używane w sposób instrumentalny dla dobra innych, naturalnie narodzonych ludzi? Barilan posuwa się nawet do stwierdzenia, że obecna wykładnia rabiniczna, łącznie z oficjalnym stanowiskiem izraelskiego rabinatu, który pozwala

${ }^{24}$ J. Maritain, Prawo naturalne i prawo moralne, [w:] S. Sarnowski, E. Frykowski, Problemy etyki, Bydgoszcz 1993, s. 104.

${ }^{25}$ M.Y. Barilan, dz. cyt., s. 315.

${ }^{26}$ Księga Kapłańska, 19:9.

${ }^{27}$ M.Y. Barilan, dz. cyt., s. 315. 
na nie tylko zapłodnienie in vitro, ale także klonowanie reprodukcyjne, nie może być traktowana jako dojrzała postawa ${ }^{28}$.

Judaistyczny dyskurs bioetyczny pozbawiony jest sformułowań obecnych na przykład w bioetyce chrześcijańskiej i zachodniej, takich jak „działanie przeciw naturze”29, „zabawa w Boga”, „pogwałcenie ludzkiej godności”. Rabin Michael J. Broyde zatytułował nawet jeden ze swoich artykułów i wystąpienie dotyczące klonowania: In Judaism, Playing God is Good, opowiadając się za klonowaniem jako techniką wspomaganej reprodukcji ${ }^{30}$. W judaizmie bowiem nie ma sprzeciwu wobec jakichkolwiek korzystnych zmian, dopóki nie są one zakazane w Torze.

Naturalne i oczywiste wydaje się prawo każdej społeczności do działania dla swojej korzyści i w obronie swoich interesów. Prawo rabiniczne odróżnia prawa ogólne od zasad ustanowionych przez rabinów dla lokalnych społeczności, które podyktowane są miejscowymi uwarunkowaniami i okolicznościami, i mają, z zasady, charakter tymczasowy. Biorąc to pod uwagę, Barilan uznaje, że obecne nauczanie rabinów w sprawie klonowania czy badań na embrionach jest tymczasowe. Współcześnie nie można uznać klonowania, które jest raczej potencjalne niż realne, za całkowicie zabronione, brak ku temu, póki co, wystarczających przesłanek ${ }^{31}$. Nie brak jednak głosów, że halacha nie ogarnia całego bogactwa współczesnego życia publicznego, dlatego też nawołuje się do tymczasowego zabronienia klonowania ${ }^{32}$. Podobne stanowisko przyjmuje jeden $\mathrm{z}$ głównych autorytetów $\mathrm{w}$ tej dziedzinie rabin Michael J. Broyde, zastanawiając się, czy klonowanie nie powinno być tymczasowo zabronione. Dochodzi jednak do wniosku, że może być ono dozwolone pod warunkiem, że służy wyłącznie jako technika wspomaganej reprodukcji ${ }^{33}$.

Bioetyka judaistyczna nie podejmuje takich zagadnień, jak „projektowanie dzieci”, „prawo do otwartej przyszłości” czy „prawo do

${ }^{28}$ Tamże, s. 316.

29 Porównaj stanowisko Fukuyamy w sprawie natury ludzkiej jako fundamentu porządku społecznego, moralnego i politycznego. Ingerencja w naturę ludzką, na przykład za pomocą rekombinacji DNA, klonowania etc. doprowadzić może do zachwiania systemu wartości i zaburzenia relacji społecznych, jako że wynikają one bezpośrednio z natury ludzkiej, naszej specyfiki gatunkowej: F. Fukuyama, Koniec człowieka. Konsekwencje rewolucji biotechnologicznej, przeł. B. Pietrzyk, Kraków 2004, s. 23-29, 119-120.

${ }^{30}$ M.J. Broyde, In Judaism, Playing God is Good, "Voices Across Boundaries", Winter 2004, nr 4, s. 31-34.

${ }^{31}$ M.Y. Barilan, dz. cyt., s. 317.

32 Tamże, s. 318.

${ }_{33}$ M.J. Broyde, Jewish Medical Ethics: Cloning People and Jewish Law, Medical Ethics, Jewish Virtual Library, https://www.jewishvirtuallibrary.org/cloning-peopleand-jewish-law [dostęp: 8.10.2018]. 
genetycznej unikatowości" ${ }^{34}$. W przypadku sztucznego zapłodnienia albo klonowania kluczowe są relacje rodzinne i zachowanie integracji rodziny ${ }^{35}$, podobnie jak w kulturze konfucjańskiej i bioetyce muzułmańskiej. Definiowanie ojcostwa i macierzyństwa w judaizmie ma swe korzenie w prawie religijnym. Zgodnie z tradycyjną religijnością prawne ojcostwo nie może być oddzielone od biologicznego. $Z$ tego też względu odrzuca się zapłodnienie in vitro, jeśli dawcą spermy nie jest małżonek ${ }^{36}$. Jeśli chodzi o macierzyństwo, uważa się, że jest ono zdeterminowane przez urodzenie dziecka, a nie przez geny. Czyli jako matka traktowana byłaby surogatka, a nie dawczyni komórki jajowej. Istnieją jednak interpretacje zakładające, że zarówno kobieta, która rodzi dziecko, jak i dawczyni komórki jest matką dziecka. Rozbieżności te wynikają z kazuistycznego charakteru judaistycznej etyki, analizuje się poszczególne przypadki, które niekoniecznie zyskują normatywny wydźwięk.

Judaistyczne podejście do definicji macierzyństwa i ojcostwa połączone $\mathrm{z}$ religijnym obowiązkiem posiadania dzieci doprowadza niektórych komentatorów do uznania zasadności klonowania prokreacyjnego ${ }^{37}$. Obowiązek posiadania dzieci musi zostać spełniony, choćby przebiegało to $\mathrm{w}$ niecodzienny sposób, większość współczesnych uczestników debaty dotyczącej klonowania zgadza się co do dopuszczalności terapeutycznego klonowania ${ }^{38}$. Jedną z konsekwencji może być ułatwienie samotnego macierzyństwa w sposób, który nie jest sprzeczny z halacha. Sytuacja ta budzi pewne obawy konserwatystów, daje bowiem furtkę kobietom na macierzyństwo $\mathrm{z}$ uniknięciem małżeństwa, a zatem podważa to instytucję małżeństwa i rodziny jako takiej. Zgodnie z prawem religijnym bowiem dziecko poczęte na skutek nielegalnego związku żydówki z niewolnikiem jest traktowane jako dziecko bez ojca. Sperma biologicznego ojca, jak się uważa, nie wpływa zasadniczo na tworzenie się zarodka, poza pobudzeniem go do podziałów. W takiej sytuacji matka bierze na siebie biologiczną i prawną rolę matki oraz prawną rolę ojca. Tradycyjnie żydostwo dziedziczy się

\footnotetext{
${ }^{34}$ Por. J. Habermas, Przyszłość natury ludzkiej. Czy zmierzamy do eugeniki liberalnej, przeł. M. Łukasiewicz, Warszawa 2003.

${ }_{35}$ M.J. Broyde, Jewish Medical Ethics..., dz. cyt.

${ }^{36}$ M.Y. Barilan, dz. cyt., s. 324.

${ }^{37}$ M.J. Broyde, Jewish Medical Ethics..., dz. cyt.

${ }^{38}$ Sh. Samber, Cloning Debate in Judaism, My Jewish Learning, https://www.myjewishlearning.com/article/the-cloning-debate-in-judaism/ [dostęp: 8.10.2018]; S.J. Werber, Cloning: A Jewish Law Perspective With A Comparative Study of Other Abrahamic Traditions, "Seton Law Review" 2000, vol. 30:1114, s. 1130-1132.
} 
po matce, a nie ojcu, którego rola jest tu drugorzędna ${ }^{39}$. Takie postępowanie sprzyja posiadaniu dzieci przez kobiety (nawet niezamężne) za pomocą np. sztucznego zapłodnienia, gdy dawca spermy jest anonimowy, albo w przyszłości, dzięki klonowaniu. Brak udziału spermy przy prokreacji za pomocą klonowania w interpretacji niektórych autorytetów powoduje, że sklonowane dziecko nie ma ojca ${ }^{40}$.

Podstawową kwestią w przypadku reprodukcji, bez względu na to, czy jest ona sztucznie wspomagana, czy nie, jest uniknięcie sprowadzania na świat dzieci pochodzących z niedozwolonych związków (mamzer), np. kazirodztwa i cudzołóstwa, ale nie chodzi tu o dzieci nieślubne w ogóle. Mamzerem nie jest bowiem nieślubne dziecko żydówki, która nie wyszła za mąż, jeśli ojcem był nieżonaty żyd (nie było więc cudzołóstwa). Osoby określane jako mamzer, nie tylko że same nie mogą zawierać związków małżeńskich z „prawowitymi” żydami, to również zakaz ten dotyczy ich potomków ${ }^{41}$. Status mamzera jest dziedziczny. Mamzer lub potomek mamzera poślubić może jedynie innego mamzera lub konwertytę. Mimo pozytywnego stosunku rabinów do klonowania w ramach małżeństwa, biorąc pod uwagę, że klonowanie ludzi jest ciągle sprawą hipotetyczną, Barilan obawia się, że społeczna stygmatyzacja dzieci z nieprawidłowych związków (mamzer) w praktyce skutkować może również stygmatyzacją i wykluczeniem dzieci, które przyjdą na świat w drodze klonowania ${ }^{42}$.

Ponieważ nie tyle samo klonowanie czy wspomagana reprodukcja budzą kontrowersje, ile to, czy związek i dziecko z niego powstałe są obyczajowo prawidłowe, dlatego samo klonowanie, dopóki służy jako narzędzie wspomagania prokreacji pary małżeńskiej, jest popierane przez wielu rabinów ${ }^{43}$. Przewagą klonowania w ramach pary małżeńskiej z tego punktu widzenia, stwierdzają zgodnie Broyde i Barilan, jest to, że nie komplikuje ono podziału ról rodzicielskich (jeśli dziecko jest klonem męża, a ciążę nosi żona) ${ }^{44}$. Kwestia klonowania i warunków jego dopuszczalności odnosi się tutaj nie do metafizycznego statusu klonowanego, ale do relacji rodzinnych, tak aby nie podważało ono ojcostwa, macierzyństwa i prawidłowości związku oraz nie niosło ryzyka wprowadzenia obcego, nieżydowskiego elementu.

\footnotetext{
${ }^{39}$ M.Y. Barilan, dz. cyt., s. 324.

${ }^{40}$ Zob. M.J. Broyde, Jewish Medical Ethics..., dz. cyt.

41 Księga Powtórzonego Prawa 23:2.

42 M.Y. Barilan, dz. cyt., s. 327.

43 Tamże, s. 325.

44 Tamże.
} 
Judaizm kładzie duży nacisk na właściwe pochodzenie dzieci, te więc kwestie są szczególnie istotne w kontekście klonowania. Dziecko pochodzące tylko z określonego prawidłowego związku jest żydem oraz może poślubić innego żyda. Jasność pochodzenia dziecka jest istotnym, jeśli nie kluczowym elementem tożsamości religijnejej ${ }^{45}$. Dlatego podkreśla się, aby klonowanie albo inne formy wspomaganej reprodukcji odbywały się wewnątrz małżeństwa ${ }^{46}$.

Barilan, odnosząc się do judaistycznej tradycji religijnej, wnosi inne zastrzeżenia wobec klonowania. Powołuje się na prawo religijne zawarte w Szulchan aruch, które zabrania małżeństwa, jeśli jest pewne, że z tego związku narodziłoby się dziecko obciążone poważnym schorzeniem, jak na przykład epilepsją. Według niego reguła ta zobowiązuje do zabronienia klonowania ludzi przy obecnym stanie wiedzy i poziomie rozwoju technologii ${ }^{47}$. Klonowanie ssaków poprzedzone było wieloma nieudanymi próbami, nawet dziś tylko niewielki procent ciąż kończy się rozwiązaniem, tylko niektóre płody rozwijają się w pełni w prawidłowy sposób. Nie ma gwarancji, że dzieci poczęte na skutek zastosowania techniki klonowania metodą transferu jądra komórki somatycznej przyszłyby na świat zdrowe. Kolejne wysuwane przez niego zastrzeżenie wobec klonowania dotyczy możliwości nowej eugeniki. Nasuwać się bowiem może myśl i pragnienie, aby klonowane dzieci udoskonalać wobec swych „pierwowzorów”. Pojawić się może także pokusa, aby identyczne genetycznie osobniki traktować jako dawców organów i tkanek na przeszczepy.

Konkludując, zarówno rabin Broyde oraz rabin Tendler, jak i lekarz Barilan zgodnie stwierdzają, że klonowanie jako technika wspomaganej reprodukcji, jeśli nie ma innych możliwości na wypełnienie obowiązku spłodzenia potomstwa, powinno być dozwolone. Sklonowane dzieci należy traktować z szacunkiem należnym każdej istocie ludz$\mathrm{kiej}^{48}$. Ponieważ stanowisko judaistyczne podkreśla rolę biologicznego rodzicielstwa, klonowanie będzie preferowaną formą leczenia bezpłodności w porównaniu $\mathrm{z}$ wykorzystywaniem gamet pochodzących od dawców spoza małżeństwa lub przez wykorzystanie zbędnych zarodków innych par, które stosowały sztuczne zapłodnienie in vitro $\mathrm{z}$ powodzeniem.

\footnotetext{
45 Tamże, s. 331-332.

46 M.J. Broyde, In Judaism, Playing..., dz. cyt., s. 32-33.

47 M.Y. Barilan, dz. cyt., s. 328.

${ }^{48}$ M.J. Broyde, Jewish Medical Ethics..., dz. cyt.
} 


\section{Problematyka końca życia i pobierania organów od zmarłych}

Jeśli chodzi o zagadnienia końca życia, podejście judaistyczne cechuje się znacznie mniejszą elastycznością, wszelkie formy aktywnej i nawet pasywnej eutanazji traktuje się jako morderstwo, a jest ono absolutnie zakazane zgodnie z przykazaniem „nie zabijaj” ${ }^{49}$. Potępiający stosunek wobec aktywnej eutanazji zawarty jest także w Talmudzie i tradycji rabinicznej, gdzie ,pomaganie w odejściu na tamten świat” jest traktowane jako przelanie krwi, morderstwo ${ }^{50}$. Akt aktywnej eutanazji jest tam opisywany plastycznie jako zamykanie oczu lub zabieranie poduszki umierającemu ${ }^{51}$. $\mathrm{O}$ ile więc status zarodków, embrionów i płodów nie jest jednoznaczny, co pozwala na dokonywanie na nich pewnych manipulacji, jak zapłodnienie in vitro, PDG, badania w kierunku opracowania nowych sposobów leczenia, włączając $w$ to nawet przeprowadzanie aborcji w sytuacji zagrożenia dla matki, o tyle status osoby umierającej jest jednoznaczny, a uśmiercenie takiej osoby równa się bezwzględnie morderstwu ${ }^{52}$. Również proces umierania nie jest tu stopniowany ani relatywizowany. Pod względem stanowczego potępienia eutanazji, przy jednoczesnym niejednoznacznym statusie życia prenatalnego, przyzwoleniu na klonowanie lub eksperymenty naukowe na embrionach, a nawet na wczesnym etapie ciąży na aborcję, podejście judaistyczne jest najbardziej zbliżone do islamskiego ${ }^{53}$.

W odniesieniu do przeprowadzania transplantacji zasadnicza pozytywna recepcja tego zabiegu $\mathrm{w}$ judaizmie opiera się na talmudycznej zasadzie, że kiedy życie ludzkie jest stawką, to niesienie pomocy zagrożonemu życiu ludzkiemu jest ważniejsze niż inne reguły prawne i rytualne. Przykładem jest nakaz ratowania nienarodzonego życia, kiedy matka umiera, a można wyczuć ruchy płodu, należy je ratować nawet w szabat, w czasie którego normalnie nie można podejmować pracy $^{54}$. Priorytet ratowania ludzkiego życia przyzwala na przeprowadzanie transplantacji, jednak, podobnie jak w przypadku bioetyki

${ }^{49}$ F. Rosner, The Jewish Attitude Toward Euthanasia, [w:] F. Rosner, D.J. Bleich (red.), Jewish Bioethics, New York 1983, s. 260.

${ }^{50} \mathrm{Za}$ : tamże, s. 261.

51 Tamże, s. 262.

52 Tamże, s. 263.

${ }^{53}$ Sh. Hamdy, Not quite dead: Why Egyptian Doctors Refuse the Diagnosis of Death by neurological criteria, "Theoretical Medicine and Bioethics" 2013, vol. 34, nr 2, s. $147-160$.

${ }^{54}$ N.L. Rabinovitch, What is the Halakhah for Organ Transplantants?, [w:] F. Rosner, D.J. Bleich (red.), Jewish Bioethics, New York 1983, s. 353-354. 
islamskiej czy buddyjskiej albo konfucjańskiej, w praktyce natrafia to na rozmaite przeszkody rytualne, co hamuje powszechną akceptację takich zabiegów.

Przeszkody rytualne zniechęcają do dawstwa organów w Chinach, gdzie tradycyjnie w konfucjanizmie przed kremacją lub pochówkiem integralność ciała nie powinna być naruszana, ciało bowiem jest darem od rodziców i szacunek do rodziców nakazuje dbanie o nie, a także zachowanie integralności cielesnej również po śmiercis5. Chociaż więc idea miłosierdzia i człowieczeństwa (ren), będąca podstawową wartością w konfucjanizmie, skłania ku pośmiertnej donacji organów, to rytualne wymogi pogrzebu w praktyce odstręczają Chińczyków od pośmiertnego oddawania organów, co prowadzi do handlu organami, pozyskiwanymi od straconych, często politycznych więźniów ${ }^{56}$. W buddyzmie natomiast ciało tuż po śmierci nie powinno być dotykane, aby nie zaburzać procesów powtórnej inkarnacji, co również stwarza przeszkodę dla pobierania organów, mimo iż nauczanie buddyjskie oficjalnie opowiada się za taką formą ratowania życia ludzkiego jako wyrazu najwyższego współczucia. Podobnie w judaizmie, chociaż ratowanie życia przez transplantację organów jest uważane za dobry uczynek, to jednak rytuały pogrzebowe oraz przekonania dotyczące śmierci i godności zmarłego skutecznie przeciwdziałają oddawaniu organów.

W judaizmie istotna jest, opisana już wcześniej, idea godności ciała zmarłego, która w praktyce zniechęca nie tylko do zabiegów pośmiertnego pobierania organów, ale także przeprowadzania sekcji zwłok. Zabiegi wykonywane na zwłokach interpretowane są jako jej pogwałcenie. Nie tylko operacje, ale także dotykanie zmarłego ciała, wystawianie go na pokaz, a nawet opóźnianie pochówku uważane są za naruszenie godności zmarłego. Zmarły nie powinien być dotykany, z wyjątkiem rytualnego oczyszczenia, ani jego ciało nie powinno być eksponowane na widok publiczny, a pogrzebu należy dopełnić bez zbędnej zwłoki, jak najszybciej ${ }^{57}$. Kolejny czynnik zniechęcający do zgody na pobranie organów to zakaz czerpania jakichkolwiek korzyści z czyjejś śmierci.

${ }^{55}$ Q. Ren-Zong, The Tension Between Biomedical Technology and Confucian Values, [w:] J. Tao Lai (red.), Cross-Cultural Perspectives on (Im)Possibility of Global Bioethics, London 2002, s. 76-78.

${ }^{56} \mathrm{C}$. Yu, On the Impact of Traditional Chinese Culture on Organ Donation, "Journal of Medicine and Philosophy" 2013, nr 38, s. 149-159.

${ }_{57}$ F. Rosner, Autopsy in Jewish Law and the Israeli Autopsy Controversy, [w:] F. Rosner, D.J. Bleich (red.), Jewish Bioethics, New York 1983, s. 335. 
W przypadku zarówno autopsji, jak i pobierania organów od zmarłych pojawia się również problem pochówku, po pobraniu organów nie można bowiem pochować ciała w całości w tym samym czasie, czego wymaga prawo religijne ${ }^{58}$. W Izraelu istnieje nawet specjalna organizacja ZAKA, która powołana została pod koniec lat 80 . XX w. do tego, aby z miejsc zamachów i wypadków zbierać najmniejsze nawet szczątki ofiar lub ślady krwi, aby je należycie pochować. Wolontariusze rekrutujący się głównie ze środowisk religijnych towarzyszą ekipom karetek pogotowia ${ }^{59}$.

Tradycyjna postawa wobec śmierci i umierania bardzo mocno wpływa na prawodawstwo w Izraelu. Do 1953 r. nie istniały regulacje prawne dotyczące wykonywania autopsji czy darowania swoich zwłok na cele naukowe, co utrudniało nie tylko śledztwa, ale także kształcenie przyszłych lekarzy. W $1953 \mathrm{r}$. wprowadzono prawo zezwalające na podobne zabiegi jedynie za zgodą rodziny lub w przypadku nadzwyczajnych okoliczności. W latach 60. i 70. XX w. mimo silnego nacisku ze strony autorytetów medycznych nie zmieniono tego prawa. W 1980 r. wprowadzono zasadę, że sekcji zwłok dokonać można jedynie za zgodą rodziny, a rodziny przeważnie odrzucają taką możliwość. Znane są sytuacje, gdy nawet w przypadku morderstwa nie wykonywano autopsji z powodów religijnych właśnie ${ }^{60}$. Co więcej, nie należą do rzadkości sytuacje, gdy bliscy pilnują ciała, aby nie zostało ono wykradzione i pogrzebane przez ortodoksyjnych członków rodziny przed wykonaniem koniecznych badań medycznych ${ }^{61}$.

W przypadku dawstwa organów od osób żywych zasadniczym problemem jest ocena ryzyka, na które naraża się dawca, np. w przypadku transplantacji nerek. Większość autorytetów żydowskich zastrzega jednak, że w przypadku kiedy specjaliści określają to ryzyko jako niewielkie, a potencjalne korzyści dla biorcy jako decydujące o jego dalszym przeżyciu, to podjęcie takiego zabiegu jest dopuszczalne ${ }^{62}$.

Jeśli chodzi zaś o pobieranie organów od zmarłych, wysuwane są jeszcze inne zastrzeżenia dotyczące stwierdzania śmierci. Halacha

58 Tamże.

${ }^{59}$ Zob. http://www.zaka.org.il/ [dostęp: 10.11.2017].

${ }^{60}$ Father refuses to permit autopsies of daughters, http://www.israelnationalnews. com/News/News.aspx/222630 [dostęp: 11.11.2017].

61 Informator: 42 lata, były „ortodoks”, po samobójczej śmierci siostry, która również opuściła wiele lat wcześniej ortodoksję, pilnował jej zwłok, obawiając się, że zostaną one wykradzione i pogrzebane przez pozostałych ortodoksyjnych członków rodziny (2017).

${ }^{62}$ F. Rosner, Organ Transplantation in Jewish Law, [w:] F. Rosner, D.J. Bleich (red.), Jewish Bioethics, New York 1983, s. 336. 
uznaje bowiem wyłącznie pneumatyczne kryterium śmierci ${ }^{63}$, także osoby ze stwierdzoną śmiercią mózgową, jeśli mają zachowaną pracę serca i oddychają, są uważane za żywe, a więc pobieranie witalnych organów może być interpretowane jako uśmiercanie dawcy. Wielu współczesnych rabinów uważa, że pobieranie organów może nastąpić jedynie, gdy śmierć człowieka jest jednoznacznie stwierdzona. Jednak w literaturze rabinicznej nie ma jednoznacznej zgody co do tego, jakie kryteria śmierci przyjąć za definitywne - to opierające się na zatrzymaniu oddechu czy neurologiczne kryterium śmierci mózgu ${ }^{64}$. W praktyce szczególnie wśród ortodoksyjnych żydów wciąż dominuje interpretacja, że tchnienie jest jednoznaczne z życiem. Czyli osoba ze stwierdzoną śmiercią mózgową sztucznie wentylowana nie jest uważana za zmarłą, a w konsekwencji nie można od niej pobrać organów.

W podsumowaniu stwierdzić trzeba, że transplantacja i pobieranie organów nawet od zmarłych jest dopuszczalne, jeśli służy ratowaniu życia człowieka i ten imperatyw jest ważniejszy niż inne prawa i rytuały. Jednak w praktyce wielu religijnych żydów nie akceptuje pobierania organów, ponieważ jeśli potencjalni dawcy mają zachowaną czynność oddychania, uważa się ich za wciąż żywych lub też nie akceptuje się transplantacji ze względu na to, że jest to sprzeczne $\mathrm{z}$ rytuałami pogrzebowymi, zgodnie z którymi ciało powinno być pochowane bez naruszania jego integralności fizycznej.

\section{Podsumowanie}

W Izraelu istnieje duża wolność badań naukowych, swoboda badań na ludzkich embrionach i embrionalnych komórkach macierzystych dorównuje najbardziej liberalnym rozwiązaniom pod tym względem, jak w Wielkiej Brytanii, Stanach Zjednoczonych czy Chinach. Dynamiczny rozwój biotechnologii, biomedycyny oraz start-upów i technologii elektronicznych stanowią symbol współczesnego, nowoczesnego społeczeństwa Izraela. Również stosunek do aborcji uległ w ostatnich dekadach znacznej liberalizacji, choć wśród żydów ortodoksyjnych jest nadal potępiana. Nawet jednak wśród środowisk ortodoksyjnych dopuszcza się sztuczne zapłodnienie czy PDG, wiążące się z ingerencją w rozwój zarodka. Wydaje się, że w tych przypadkach istotną rolę odgrywa brak jednoznacznego, normatywnego i konsekwentnego stanowiska judaizmu w sprawie statusu życia prenatalnego, które na róż-

${ }^{63}$ D.J. Bleich, Establishing Criteria of Death, [w:] F. Rosner, D.J. Bleich (red.), Jewish Bioethics, New York 1983, s. 280-281.

${ }^{64}$ F. Rosner, Organ Transplantation..., dz. cyt., s. 336-337. 
nych etapach może mieć inną wartość moralną. Podczas gdy tradycyjna koncepcja godności jako atrybutu zmarłego ciała oraz tradycyjne pneumatyczne kryterium stwierdzania śmierci wydaje się rzutować na zachowawcze i konserwatywne podejście do autopsji, a także pobierania organów do transplantacji czy do celów naukowych. Podobnie wpływa negatywnie na postrzeganie eutanazji i wspomaganego samobójstwa. Mimo nowoczesnego i progresywnego charakteru współczesnego społeczeństwa izraelskiego zauważyć możemy, że w kwestiach bioetycznych wpływ autorytetu religijnego jest niezwykle silny.

\section{Bibliografia}

Barilan M.Y., The debate on human cloning: some contributions from the Jewish tradition, [w:] H. Roetz (red.), Cross-Cultural Issues in Bioethics: The Example of Human Cloning, New York 2006.

Bleich D.J., Abortion in Halakhic Literature, [w:] F. Rosner, D.J. Bleich (red.), Jewish Bioethics, New York 1983.

Bleich D.J., Establishing Criteria of Death, [w:] F. Rosner, D.J. Bleich (red.), Jewish Bioethics, New York 1983.

Broyde M.J., Jewish Medical Ethics: Cloning People and Jewish Law, Medical Ethics, Jewish Virtual Library, https://www.jewishvirtuallibrary.org/cloning-people-and-jewish-law.

Broyde M.J., In Judaism, Playing God is Good, "Voices Across Boundaries”, Winter 2004, nr 4.

Cai Y., On the Impact of Traditional Chinese Culture on Organ Donation, "Journal of Medicine and Philosophy" 2013, nr 38.

Eisenberg D., Stem Cell Research in Jewish Law, http://www.jlaw. com/Articles/stemcellres.html.

Father refuses to permit autopsies of daughters, http://www.israelnationalnews.com/News/News.aspx/222630.

Fukuyama F., Koniec człowieka. Konsekwencje rewolucji biotechnologicznej, przeł. B. Pietrzyk, Kraków 2004.

Gubała W., Jan Pawet II o etyce lekarskiej, [w:] P. Morciniec (red.), Ad libertatem in veritate, Opole 1996.

Habermas J., Przyszłość natury ludzkiej. Czy zmierzamy do eugeniki liberalnej, przeł. M. Łukasiewicz, Warszawa 2003.

Hamdy Sh., Not quite dead: Why Egyptian Doctors Refuse the Diagnosis of Death by neurological criteria, "Theoretical Medicine and Bioethics, 2013, vol. 34, nr 2.

http://www.zaka.org.il/. 
Jakobovits I., Jewish Views on Abortion, [w:] F. Rosner, D.J. Bleich (red.), Jewish Bioethics, New York 1983.

Kamin D., Israel's abortion law now among world's most liberal, “The Times of Israel”, http://www.timesofisrael.com/israels-abortionlaw-now-among-worlds-most-liberal/.

Księga Kapłańska, 19:9.

Księga Powtórzonego Prawa 23:2.

Księga Wyjścia, 21:22-23.

Maritain J., Prawo naturalne i prawo moralne, [w:] S. Sarnowski, E. Frykowski (red.), Problemy etyki, Bydgoszcz 1993.

Müller D., The Role and Influence of Religions in Bioethics, [w:] R.M. Green, A. Donovan, S.A. Jauss (red.), Global Bioethics. Issues of Conscience for the Twenty-First Century, Oxford 2008.

Potter V.R., Bioethics. Bridge to the Future, Prentice-Hall, New Jersey 1971.

Qiu Ren-Zong, The Tension Between Biomedical Technology and Confucian Values, [w:] J. Tao Lai (red.), Cross-Cultural Perspectives on (Im)Possibility of Global Bioethics, London 2002.

Rabinovitch N.L., What is the Halakhah for Organ Transplantants?, [w:] F. Rosner, D.J. Bleich (red.), Jewish Bioethics, New York 1983.

Raz A.E., Vizner Y., Carrier matching and collective socialization in community genetics: Dor Yeshorim and the reinforcement of stig$m a$, "Social Science and Medicine" 2008, nr 67.

Rosner F., Artificial Insemination in Jewish Law, [w:] F. Rosner, D.J. Bleich (red.), Jewish Bioethics, New York 1983.

Rosner F., Autopsy in Jewish Law and the Israeli Autopsy Controversy, [w:] F. Rosner, D.J. Bleich (red.), Jewish Bioethics, New York 1983.

Rosner F., Organ Transplantation in Jewish Law, [w:] F. Rosner, D.J. Bleich (red.), Jewish Bioethics, New York 1983.

Rosner F., Reichman E., Embryonic Stem Cell Research in Jewish Law, "The Journal of Halacha and Contemporary Society" 2002, nr XLIII.

Rosner F., The Jewish Attitude Toward Euthanasia, [w:] F. Rosner, D.J. Bleich (red.), Jewish Bioethics, New York 1983.

Samber Sh., Cloning Debate in Judaism, My Jewish Learning, https:// www.myjewishlearning.com/article/the-cloning-debate-in-judaism/.

Tendler M., Cloning in Jewish Law, YU Medical Ethics: Creating in God's Image?, Yeshiva University, 23.01.2003, https://www.yutorah.org/lectures/lecture.cfm/717528/rabbi-moshe-d-tendler/cloning-in-jewish-law/28-31 min. 
Werber S.J., Cloning: A Jewish Law Perspective With A Comparative Study of Other Abrahamic Traditions, "Seton Law Review" 2000, vol. 30:1114.

\section{Summary}

\section{Jewish bioethics at the beginning and the end of life}

The article is focused on Israeli bioethical specificity, which derive from and is based mainly on Jewish religious law and tradition. They are actively reinterpreted and implemented in Israeli society by social practices, polices and institutions. This topic is complex because the differences between the orthodox, conservative, and reformed Judaism are reflected in bioethical discussions. However in Israel a broad consensus has been reached on many issues such as abortion, in vitro fertilization, preimplantation genetic diagnosis, human cloning, stem cell research including embryonic stem cells, and euthanasia. Generally speaking, similar like Islamic and Confucian bioethics, the Jewish one is open to the possibility of artificial in vitro fertilization, PGD, human cloning, and embryonic stem cell research. On the other hand, the attitudes towards euthanasia, autopsy and organ donation in Jewish bioethics are largely negative. 